b) Elblag University of Humanities and Economy, Poland https://orcid.org/ 0000-0003-1561-6636

c) Faculty of Economics, University of Gdańsk, Poland

https://orcid.org/ 0000-0001-8463-9845

\title{
ORGANIZATION AND MANAGEMENT OF DEREGULATED AND REGULATED PUBLIC TRANSPORT ON THE EXAMPLE OF WEST YORKSHIRE METROPOLITAN AREAS AND THE GULF OF GDAŃSK - SIMILARITIES AND DISCREPANCIES
}

\begin{abstract}
In urban transport, two basic models of organization and management of its functioning are used, i.e. a model of deregulated and regulated transport. The article presents the main assumptions and principles of both models, based on the literature review and the results of research on similarities and discrepancies that take place in practice on the example of two metropolises: West Yorkshire in the United Kingdom and the metropolis of the Gulf of Gdansk in Poland. When making comparisons, organizational structures appearing on the market, organizers' and operators' tasks, ownership forms of organizers and operators, operators' shares in the transport services market, tariff and ticket solutions as well as the scope of concessions for free and reduced journeys were taken into account. Particular attention was paid to the integration of transport services of individual organizers, focusing on the influence of the level of integration on the quality of transport services. In the further part of the article, issues requiring discussion in the light of the presented research results were pointed out and a summary of the substantive considerations was carried out within its framework. It was also stated that the research hypothesis was proved, according to which the deregulated and regulated transport models show in practice more similarities than discrepancies.
\end{abstract}

Keywords: public transport, urban areas, organization, management

JEL: R41 


\section{Introduction}

In public transport functioning in servicing metropolitan areas, two basic models of organization and management are applied: deregulated and regulated. In principle, these are fundamentally separate systems. In practice, however, there are far-reaching similarities between them, which are the result of the public authorities' striving to provide the residents of these areas with a high standard of transport services. As a result, the extent of the discrepancy between these systems became very limited. This issue may be examined on the example of a particular metropolis in Great Britain where apart from London a deregulated system is used, and Poland where a regulated system is generally in force. The authors of this article, due to their professional involvement, are the closest to the systems of organization and management of public transport in the West Yorkshire metropolis in Great Britain and the metropolis of the Gulf of Gdańsk in Poland.

The aim of the article is to present the principles of functioning in practice of a deregulated and regulated system of organization and management of public transport in a metropolitan area. According to the research hypothesis adopted in the article, these models show in practice more similarities than discrepancies.

\section{Literature review}

Many publications have been devoted to the organization and management of public transport in metropolitan areas.

Organizational forms of local public transport can be brought to two opposite solutions: one based on public intervention and the other using a market mechanism (van de Welde, 1999). In case of public interference, public authorities managing public transport services have a legally guaranteed monopoly on the provision of these services and decide in a more or less detailed manner what services must be provided. This means that independent entry into the market is formally prohibited and that entities belonging to public authorities directly provide services or commission contracted entities to provide transport services. However, in the case of using the market mechanism, independent entry onto the market is possible. Competent authorities act as a licensor mainly verifying that the potential producer of services meets legal requirements as well as technical and operational standards. They also assess the compliance of the market initiative with the strategic objectives and strategy of the area (Zatti, 2011).

The main problem of public authorities deciding to commission transport services is the choice of a particular contracting method. The provision of these services is associated with two types of risks: costs and revenues. The first one concerns the possibility of exceeding a certain level of costs, the second - failure to achieve a certain level of revenues. In the situation where the operator bears only the cost risk, a gross cost contract is concluded, whereas if the operator also incurs income risk, the net cost contract is concluded (Zhang et al., 2016). 
The provision of local public transport services in Europe has undergone significant changes in the last few decades. These changes, which were the result of regulatory reforms, both at the European and national level led to institutional changes in the organization and management of public transport. EU Regulation $1370 / 2007$ completed the nearly 40 -year validity period of the previous regulation. The current regulation leaves the local transport authorities free to choose to provide transport services directly on their own or to delegate the role of providing services to external operators, selected on the basis of tenders (Florio et al., 2013).

The biggest step towards deregulation in Europe was made in the UK by resolving the Transport Act in 1985. This law introduced deregulation of bus services in the United Kingdom, except for Northern Ireland and the metropolitan area of London. The Transport Act abolished quantitative licenses and forced local authorities to sell their municipally owned public transport companies. Public owned enterprises were privatized in small enough sections to prevent any private market dominance by the operator (Florio et al., 2013).

In the UK, general responsibility for transport policy is placed under the Department for Transport (DfT). There are two types of structures at the local level:

- single-tier or "unitary" authorities, located in Wales and Scotland, and in some parts of England, having responsibility for all functions below national and regional level,

- two-tier authorities, occurring in most parts of England. Placed under country councils.

Both structures are road and transport management. They bear direct responsibility for the maintenance and construction of local roads. They support non-commercial bus services, usually by organizing tenders for their provision. They also play a specific role in the promotion of public transport, providing consistent information on timetables. They also allocate large public funds for school transport, fulfilling their statutory duties in this area. What's more, they stimulate the use of rail transport. They also provide financing for certain concessions in fares, including children, the elderly and people with disabilities (White, 2017).

As part of the deregulation of local public transport in the United Kingdom, the Passenger Transport Authorities (PTAs) operating until then, became bodies consisting of elected members from district councils in their areas. In 2008, under the Local Transport Act, they were granted wider powers, changing their name to Integrated Transport Authorities (ITAs). As part of these structures, the current responsibility for the operation of local transport has been placed upon the Passenger Transport Executive (PTE). These units employ professional managers. The creation of Combined Authorities (CAs) has become possible in the largest metropolises. These structures have a wide range of local authorities in the field of transport and planning on a metropolitan scale (White, 2017).

In Poland, after the end of World War II, the organization and management of public transport in cities was carried out by voivodeship and municipal transport companies with the status of state-owned enterprises. Thanks to this, public transport services in cities within the voivodeship were internally integrated. However, the socialist economic system did not allow the proper implementation of individual management following the example of solutions used in the market economy. 
As a result, local public transport was unable to provide the level of service desired by passengers. Nevertheless, it played a dominant role in satisfying transport needs, due to the marginal share in the transport of individual motorisation (Wyszomirski, 2002).

The major change in the conditions of the functioning of cities followed the adoption in 1990 of the Act on municipal self-government. This Act initiated the process of restructuring urban transport in Poland (ustawa o samorządzie gminnym, 1990) Under this law, municipal authorities, instead of state-owned ones, have become responsible for providing local public transport services. They had to decide on the choice of specific solutions for the organization and management of urban transport. Municipalities gained the possibility of deregulation and market liberalization. Some municipalities decided to take advantage of this possibility and began to use the competition mechanism in order to market the verification of the efficiency of transport enterprises and to create high-quality transport services. In these cases, there has been a change in the orientation in shaping the transport service from production to marketing. The basis of the marketing approach to customers has become the results of market research (Rucińska, 2015).

A characteristic feature of the initial period of the 1990s was the possibility of flexible shaping of market organization rules and the way of contracting transport services. As a result, some municipalities started implementing new market organization models, admitting that the current manner of its organization consisting in the monopoly of a municipal enterprise combining the organization and implementation functions did not provide the benefits of a market economy. There were attempts to deregulate the market, but in practice a solution known as regulated competition found its application. As part of this solution, the organization and implementation of transports were separated in metropolises and large cities and public transport management was entrusted to specialized units that could employ competitive operators. The first city in Poland where it was made was Białystok in 1991, followed by Gdynia, part of the metropolis of the Gulf of Gdańsk and the Polish capital - Warsaw in 1992 (Dydkowski, 2009).

With time, urban transport, as a field of management, began to be subject to an increasing number of regulations. None of these regulations was prepared specifically for this transport. Their number grew rapidly, making it possible to talk about administration and not about managing public transport in metropolises and cities. A strong lobby of opponents of competition in road transport initiated the beginning of works aimed at regulating the functioning of public transport, primarily with a view to adapting Polish law to Regulation 1370/2007 of the European Parliament and of the Council of 23 October 2007 enabling the direct administration of services to an internal entity in under the so-called entrusting (Grzelec, 2011).

In 2011, the Act on public mass transport entered into force (ustawa o publicznym transporcie zbiorowym, 2010). The Act sets out the rules for the organization and functioning of regular passenger transport in public transport. It introduced many uniform and relatively precise regulations. They have a universal character, which is why they are not always tailored to the specifics of individual branches and types of transport. The new law worsens the conditions for free and adapted to the needs of individual local government units of the urban transport organization. 
It also increases the level of regulation by rejecting the possibility of using attributes of competition, which weakens the competitive position of collective transport against individual transport (Chaberko, Kretowicz, 2011).

\section{Organization and management of public transport in the West Yorkshire metropolitan county}

The West Yorkshire metropolitan county is located in the north of England in the Yorkshire and the Humber region. The area of the count is $2,029 \mathrm{~km}^{2}$, and the population - 2.3 million (2016). The largest city of West Yorkshire is Leeds, inhabited in 2016 by 781,743 inhabitants (Population Estimates for UK, www.ons.gov.uk). Other major cities in the county are Wakefield, Bradford, Huddersfield and Halifax.

The West Yorkshire metropolitan county covers 5 districts: Kalderdale, Kirklees, the city of Bradford, the city of Leeds and the city of Wakefield. In 1974-1986 West Yorkshire was an administrative unit. In 1986 the metropolitan county lost its administrative powers and its constituent boroughs, called districts, became autonomous administrative units, or unitary authorities (Encyclopedia Britannica, www.britannica.com).

The public transport regulatory activity in the West Yorkshire metropolitan area is dealt with by the West Yorkshire Combined Authority (WYCA). In 2014, this entity absorbed the West Yorkshire Integrated Transport Authority as the successor of the West Yorkshire Passenger Transport Authority. The latter entity was established in 1986 as a result of the deregulation of public transport in Great Britain. WYCA has responsibility for transport, economic development and regeneration in five West Yorkshire districts.

The current management of public transport in the Leeds metropolitan area is handled by West Yorkshire Passenger Transport Executive. This entity is based in Leeds and was established in 1974. It plays the role of a metropolitan public transport board. Currently, as the West Yorkshire Integrated Transport Authority, it is a part of the West Yorkshire Combined Authority (www.wymetro.com).

The West Yorkshire Combined Authority develops a transport strategy for the entire West Yorkshire area. This entity was created to bring together the economic development and transport functions in a more strategic way. The latest strategy covers the period up to 2040. It is based on the conviction that an appropriate transport system is needed to develop this area in a way that benefits everyone living and working there. The strategy adopted the following transport development objectives:

- create a more reliable, less congested and better connected transport network,

- have a positive impact our built and natural environment,

- put people first to create a strong sense of place.

In accordance with the strategy, the condition of achieving its goals is the functioning of a single public transport system (transport-strategy-2040.pdf; www. westyorks-ca.gov.uk). 
West Yorkshire Bus Strategy 2040 is part of the overall transport strategy. The bus strategy was developed because of the role of bus transport in the county and was widely consulted in 2016. The vision of the strategy is "To create a modern, integrated and innovative bus system, which puts customers first and contributes to the delivery of the economic, environmental and quality of life ambitious as set out in the Strategic Economic Plan and the West Yorkshire Transport Strategy". The Bus Strategy sets the target to grow the number of bus passengers by up to $25 \%$ over the next ten years (West Yorkshire Bus Strategy 2040, www.westyorks-ca.gov.uk).

Public transport in the West Yorkshire area has one Metro brand, introduced in 1988. This brand is owned by WYCA. The use of a single common brand for all public transport in the county area is intended to make it easier for passengers to use transport services.

Private operators deal with provision of transport services in the West Yorkshire area. The essence of the model of deregulated public transport results in their large share in shaping the transport offer. The operators purchase rolling stock themselves, make decisions regarding the routes and the frequency of running vehicles on lines, and they themselves decide about the level of basic prices for transport services (Wyszomirski, 2001a).

However, the transport offer developed by the operators does not sufficiently achieve the strategic objectives adopted by the WYCA. This situation is the reason for interference in the transport offer by this entity. In carrying out its tasks, it undertakes certain actions aimed at improving the standard of transport services, using public funds for this purpose. These activities in particular include:

- maintaining stations and stops,

- providing information on the functioning of public transport,

- offering integrated tickets and financial support for concessionary journeys,

- ordering specific services that require funding from public funds.

Bus operators play a key role in the deregulated transport in West Yorkshire. These are only private enterprises, both small and international corporations such as Arriva, First Bus and Transdev. Each week, they carry over 3.5 million passengers. In total, the services are provided by around 40 operators, who decide on majorities of routes and timetables and set fares for them. The share of the three largest operators listed is around 90\%. WYCA doesn't run any of the buses but it contracts bus companies to run around 15\% of the county bus services - those which are important to people, but they are not profitable (West Yorkshire Bus Strategy 2040, www.westyorks-ca.gov.uk).

Arriva on its website offers Journey Planner covering not only the West Yorkshire area, but also all other UK bus connections offered by this operator. Using this site you can choose the right ticket and make a purchase (www.arrivabus.co.uk). First Bus, however, provides a website addressed to passengers traveling on a local scale in Leeds, where there are 60 bus lines of this operator and one from Leeds to Bradford. According to the offer, these are lines with a high rolling frequency of the rolling stock, e.g. every $10 \mathrm{~min}$. Via the website you can plan your trip and buy a ticket. You can also get current information (www.firstgroup.com/leeds).

WYCA together with bus companies and district councils introduced a number of bus initiatives, including: 
- YourNextBus - the live mobile timetable information via apps, SMS and mobile internet,

- two new park\&ride sites,

- Mcard - the smart multi-operator ticket scheme, used for about a third of all West Yorkshire bus trips,

- smart phone technology to provide real time information at all West Yorkshire bus stops,

- continued investment into vehicles by bus companies to make them attractive and accessible - the majority of them have low floors and $97 \%$ are fitted with smart ticketing machines (West Yorkshire Bus Strategy 2040, www.westyorks-ca.gov.uk). In addition to bus transport in the West Yorkshire transport service integrated by WYCA, under the Metro brand, there is also railway transport, partly financed from public funds by this entity. The routes of some lines extend beyond the West Yorkshire area, including neighboring cities such as Blackpool, Doncaster, Liverpool, Manchester, Nottingham, Preston, Sheffield and York. Most lines offer a high frequency. In the period from the deregulation of public transport in the West Yorkshire area, transport organizers launched almost 20 railway stations, previously closed or new, including 3 during the WYCA functioning period in 2015-2017. In 2018, this entity with key stakeholders secured funding for the redevelopment of one more station (www.wyetro.com).

As part of the effort to ensure integrated mobility in West Yorkshire, bus stations and parking lots at railway stations are being built. In addition, since 2015 the WYCA project has been implemented under the name Transport Hubs. Hubs are places where interchanges take place and where are adjacent services and facilities which make them destinations in their own right. Hubs provide easy access to the whole transport network. They are envisaged as locations on the core public transport network easily accessible by bus, rail, cycle, walking, taxi and car (www.wymetro.com).

In Leeds transport service since 1959, trams have not been functioning. From the beginning of the 90s of the previous century, transport authorities in Leeds have a new tramway system. The Leeds tramway project includes 3 lines with 50 stops and 4 large parking lots, including 4,500 parking spaces. The lines, according to the design, would be served by 40 articulated 200 local trams. The condition for the project implementation is obtaining external financing (Leeds Supertram, www.railway-technolgy.com).

A characteristic feature of deregulated public transport is the determination of types and levels of charges by operators on their own. However, this solution does not meet the requirements of passengers. As a result, transport authorities introduce, in cooperation with operators:

- entitlements to reduced fares,

- network tickets valid in all means of transport, regardless of the operator (Wyszomirski, 2001b).

In the West Yorkshire area, single tickets are sold by individual operators. However, via Metro you can get tickets with travel subsidies for young people, senior, blind and disabled persons. Children up to 5 years old travel free of charge, while between 5 and 10 years old at half the price. The 50\% discount also covers older children and young people up to 19 years of age, provided they are residents of West 
Yorkshire. In addition, students aged 19 to 25 years have some price reduction. The carrier of the discount is smartcard, smartcard, which enables to pre-load discounted bus or bus and rail weekly, monthly or termly tickets giving unlimited travel throughout West Yorkshire. The reduced senior card is available to people who have reached retirement age and are permanent residents of West Yorkshire. Metro also offers publicly available tickets with price reductions, except for one-time tickets: DaySaver, MetroDay, Weekender, DayRovers. The DaySaver ticket is valid for $1,3,5$ or 10 days only on buses. Similarly to bus transport there is a limited by its validity Weekender ticket, which can be used from Friday from 6 p.m. until midnight on Sunday, except holidays. The DayRover ticket is intended for groups of passengers up to 5 people, including a maximum of two adults or only two adults. It can be used on buses and trains outside the transport peak (www.wymetro.com).

West Yorkshire Metro also organizes free town and city buses connecting key locations around town and city centers. There is no charge to travel on that buses. They are fully accessible. The following services are free to use:

- freetownbus in Dewsbury,

- freetownbus in Huddersfield

- freecitybus inWakefield.

Freecitybus in Wakefield is characterized by the most frequent and longest operating period. Its route is round and includes 14 stops. Buses run every 10-12 minutes from 7.30 a.m. to 6.40 p.m. Monday to Friday and between 8.30 a.m. and 5.00 p.m. on Saturday (www.wymetro.com).

Freecitybus was operated under the Metro organization, also in Leeds in the years 2006-2011. Now it is called Leeds City Bus. Its route is also round and includes 19 stops. Buses run at high frequency from Monday to Saturday with high frequency during the day and in the evenings and on Sundays every 30-60 minutes. Services are provided with a small payment of 1 per journey. They are free for persons having a concessionary or season ticket. Routes of Freecitybus in Leeds are designed to connect bus and rail stations with shopping centers, hospitals, colleges, universities and key business and leisure locations. It has contributed to the reduction of city and town center congestion by encouraging people to leave their cars at home and use connecting trains and buses instead (www.wymetro.com).

\section{Organization and management of public transport in the metropolis of the Gulf of Gdańsk}

The metropolitan area of the Gulf of Gdańsk is located in the north of Poland on the Gulf of Gdańsk. The central part is created by the Tri-City, i.e. a polycentric urban area: Gdańsk (570,000 residents), Gdynia (250,000 residents) and Sopot (35,000 residents). The outer parts are the remaining towns from Tczew in the south and Wejherowo in the north. The area of the metropolitan area is $2,162 \mathrm{~km}^{2}$ and is inhabited by over 1 million people (Plan zagospodarowania przestrzennego województwa pomorskiego, 2009). 
Even before the resolution of the Act of 8 March 1990 on municipal government (ustawa o publicznym transporcie zbiorowym, 2010) which delegated competences related to the operation of local public transport to municipalities, Wojewódzkie Przedsiębiorstwo Komunikacyjne in Gdańsk, was divided into four municipal transport companies: in Gdańsk, Gdynia, Wejherowo and Tczew. As a result, in the metropolitan area of the Gulf of Gdańsk, one enterprise providing collective public transport services, was replaced by four new transport companies. A process of disintegration of public transport was also initiated, especially visible for passengers in the tariff and ticket sector.

The first, specialized organizer of public transport in the metropolitan area of the Gulf of Gdańsk is the Public Transport Authority in Gdynia (ZKM in Gdynia), which was established in 1992. It is responsible for the organization of municipal public transport in Gdynia and 6 neighboring municipalities. The statutory tasks of this organizer of urban transport include:

- examining of the urban transport market;

- designing the development of urban transport;

- development of timetables;

- concluding contracts with operators for the provision of transport services;

- control of contract performance in terms of quantity and quality;

- payment for transport services provided;

- influencing the policy of reproducing urban transport fleet;

- preparation of tariff projects;

- sale of tickets for urban transport services;

- ticket control;

- determining the necessary level of budget subsidies for urban transport services;

- maintaining stations and stops;

- current supervision of traffic and regulation of urban transport vehicles;

- preparation and provision of information on the functioning of urban transport;

- promotion of urban transport services.

Transport services for ZKM in Gdynia are carried out by three municipal companies, owned by the municipality of Gdynia: one operating exclusively trolleybuses and two - buses. In addition, private transport companies take part in transport services. Municipal operators provide services on the basis of entrustment, while private operators are selected through unlimited tenders. Gross contracts were concluded both with one and the other. The share of municipal operators in the operational operation of urban transport organized by ZKM in Gdynia in 2018 amounted to $79.9 \%$. The remaining part, i.e. $20.1 \%$, was carried out by private carriers, including the largest number of Pomeranian Transport Vehicles - 9.3\% and Bus Transport - "Gryf" - 5.1\%.

In Gdańsk, which is the largest city in the metropolitan area of the Gulf of Gdańsk, a separate public transport organizer was set up in 2005. Until then, the function of organization and implementation of transports was carried out by a municipal operator that operates trams and buses. The organizer - the Municipal Transport Authority in Gdańsk, just like the ZKM in Gdynia, is a budget entity. At the beginning of its operation, it did not perform all the tasks typical of the transport organizer, because it was still carried out by the municipal operator. This 
operator, owned by the municipality of Gdańsk, plays the main role in Gdańsk city transport. Currently, it provides transport services under the name of Gdańsk Buses and Trams, using both of these means of transport. In 2009, private operators started operating in Gdańsk city transport, who won for the first time announced tenders for eight years of service of lines crossing the administrative borders of Gdańsk. These lines, in accordance with inter-municipal agreements, are organized by ZTM in Gdańsk and thus serve 6 communes neighboring with Gdańsk. Participation in the operation of the municipal operator is $88 \%$ and the private $12 \%$ (www.ztm.gda.pl). Gdańsk trams are also used for transporting Gdańsk. Small units make it possible to transport by internal waterways and above all are an attractive form of public transport for tourists. It entered into gross contracts with all ZTM operators in Gdańsk.

In two smaller cities included in the Tri-City metropolis: Tczew and Wejherowo, the role of the organizer of municipal transport, in their areas and areas of neighboring municipalities, is carried out by the departments of municipal offices. In Tczew, a private operator selected in an unlimited tender deals with bus transport and ticket sales and control. The operator bears the commercial risk associated with the sale of tickets, which is the result of a net contract concluded with it by the city. A similar organizational solution occurs in Wejherowo. However, the implementation of transport, the control and sale of tickets, as well as the scheduling of timetables is handled by a municipal company owned by the municipality of Wejherowo Miejski Zakład Komunikacji Wejherowo. This operator has the status of an internal operator and operates on the basis of a contract of entrustment. This contract is also a net contract. The buses of the Wejherowo operator support the city of Wejherowo and neighboring municipalities, which concluded inter-municipal agreements regarding the organization of transport services with this city. Part of the operating work is outsourced to private operators. Currently, there are three private operators, whose share is around 20\% (www.mzkwejherowo.pl).

Summing up, in the polycentric area of the Tri-City metropolis, the organization of public transport is carried out by two specialized budget units of the cities constituting the core of the metropolis, i.e. Gdańsk and Gdynia. These units are respectively the Public Transport Authority in Gdańsk (ZTM in Gdańsk) and the Public Transport Authority in Gdynia (ZKM in Gdynia). In the remaining area of the metropolis, the municipal transport organizer functions as two municipal departments, i.e. in Tczew and Wejherowo. While the transport boards perform all the organizing functions, the departments of the offices have ceded some of their tasks to the operators who owned the communes, who deal with distribution and ticket control.

Restructured by separating the organizing activities from transport municipal public transport systems in the metropolis of the Gulf of Gdańsk, they provided tangible benefits to passengers, consisting in improving the quality and economic efficiency of transport services. As part of these systems, in particular Gdynia, the marketing opportunities for shaping the service offer were used based on the results of systematically conducted research on the urban transport market. This resulted in a better adaptation of the offer to the transport needs of residents. In addition, the competition mechanism in the sphere of supply of transport 
services was used to stimulate the behavior of operators that support the increase in the quality of services offered.

In the area of the metropolis of the Gulf of Gdańsk, an important role in transport service is played by Szybka Kolej Miejska (SKM - Suburban Train), launched in the 1950s from Gdańsk via Sopot and Gdynia to Wejherowo. Since 2001, the company PKP Szybka Kolej Miejska w Trójmieście Sp. z o.o. has been organizing and implementing railway agglomeration services. $z$ o.o. (SKM), which was created as a result of the restructuring of the state-owned PKP. The SKM line is treated as a ground subway, connecting the centers of the most important cities forming the metropolis, enabling efficient movement of passengers traveling through more than one municipality. SKM operates independently from public transport organized by ZTM in Gdańsk, ZKM in Gdynia and city offices in Tczew and Wejherowo, which results in the lack of integration of services provided by this transport, both in terms of organization and operation, as well as tariff and ticket. This situation reduces the quality of public transport services in metropolitan journeys.

The disintegration of municipal and railway transport entails incomplete use of all SKM's capabilities as a transport operator. Such attributes as: high commercial speed, reliability, favorable location of stops, relatively high frequency, are levelled by the lack of integration of SKM with municipal transport. Both types of public transport compete with each other and do not cooperate. SKM is a company with a state-controlled capital of the State Treasury, which in its action must take into account the need to achieve social and political goals only to the extent resulting from the subsidies of the budget of the local government to its functioning.

In 2007, the process of integrating public transport in the area of the metropolis of the Gulf of Gdańsk began. 13 cities and municipalities decided to cooperate with the aim of jointly shaping transport policy and managing local public transport. The Metropolitan Union of Communication of the Gulf of Gdańsk (MZKZG) was established, in whose statute, the implementation of individual tasks aimed at the full integration of public transport in the metropolitan area was assumed. MZKZG consists of 14 municipalities, 4 of which joined accession to this organization, including Tczew, which is one of the four organizers of municipal transport services, currently it is not a member of the union.

The entry into force of the Act on public transport caused the obligation to separate the organization from the transport. The act ordered to organize the market in the form of regulated competition, in which the public transport organizer plays a key role. The organizer's task is to plan, organize and manage public transport. The Act introduced new obligations, related to planning and contracting services. In practice, they reduce the possibility of fast adaptation of public transport to the changing expectations of passengers, because they require a procedure related to the change of plan adopted by local governments, as a source of local law and prevent quick contracting of external operators for transport services. For this reason, among others the importance of entrusting, as a form of commissioning to own, internal transport service entity grows. This has a negative impact on the course and development of competitive processes on the transport services market. In addition, the creativity of public transport 
organizers is limited due to meeting the needs of passengers and the possibility of effectively competing public transport with private transport. The Act also treats issues related to the integration of public transport in a marginal manner. There were no important provisions introduced to facilitate the real integration of public transport, in particular in highly urbanized areas.

In practice, the Act on public collective transport did not bring about any significant changes in the way public transport is managed in the metropolis of the Gulf of Gdańsk. In the two largest cities of this polycentric metropolis Gdańsk and Gdynia, changes have already been made involving the creation of municipal units performing the functions of municipal transport management boards and municipal agreements regarding the organization of public transport services in neighboring municipalities not having their own management. However, in two smaller cities Tczew and Wejherowo and neighboring municipalities, most of the tasks of the organizer are carried out by operators, in the first case private, in the second - municipal. Partial integration in the entire metropolitan area of the Gulf of Gdańsk is provided by MZKZG in the tariff-ticket aspect.

In 2008, MZKZG introduced integrated metropolitan tickets in the metropolitan area. They constitute an additional offer in relation to the currently applicable tariffs of individual urban transport organizers and railway carriers - Szybka Kolej Miejska in Trójmiasto (SKM) and Przewozy Regionalne (PR). Tickets issued by MZKZG enable journeys on the basis of one ticket using:

- only municipal transport including the services of ZTM in Gdańsk, ZKM in Gdynia and MZK Wejherowo,

- both municipal and rail transport including SKM and PR services.

Metropolitan 24-hour and 72-hour, 30-day and monthly tickets are available, as well as, only in municipal transport, single and single-hour tickets. The prices of tickets in municipal transport are passed by public authorities: the commune council in relation to the tickets of individual local organizers and the assembly of the union, in the case of integrated metropolitan tickets. The railway tariffs are approved by the local government of the Pomeranian Voivodeship.

There are different formal and legal conditions concerning the dimension and rules of reimbursement of concessions granted during transport of municipal and railway transport. These concessions in municipal transport (all in the amount of 50\%), as well as the right to free travel are granted by both central and local authorities. No compensation is granted due to their use, which means that they cause a reduction in revenues from ticket sales. In the case of railway transport, the reductions are defined by the central (national) authorities and lost revenues due to their use are compensated to rail operators from the state budget. The list of groups of people entitled to reduced and free journeys in municipal transport is very extensive, and the number of people entitled to these journeys is slowly but steadily increasing. In rail transport, the list of people entitled to reduced journeys is about half as much as in municipal transport. Public authorities do not finance any lines that are free for all passengers. 


\section{Discussion}

In the light of the comparison of organization and management of public transport presented in this study in the metropolitan areas of West Yorkshire and the Gulf of Gdańsk, specific issues require discussion.

First of all, the issue of the scope and degree of integration of the functioning of public transport in both systems requires discussion. It turns out that the deregulated system managed to achieve a greater level of integration than in the regulated system. This is related to the role of public authorities in shaping integrated public transport. It can be assumed that a regulated system does not impose a high level of integration, nor does it create a better condition for its introduction and functioning.

Secondly, in the context of the quality of services that can be achieved in both systems and their economic efficiency, it is necessary to consider how much the contracting of gross operators is necessary in a regulated system and whether it is appropriate for the public authorities to maintain operators who own them. The functioning of such operators reduces the economic efficiency of public transport and in certain conditions may also reduce the level of service quality. This is related to the politicization of the management of such entities and the large role of trade unions in the management process in these enterprises.

\section{Conclusions}

In the light of the presented considerations, the research hypothesis that the models of regulated and deregulated transport show in practice more similarities than the discrepancies can be considered proven. In both cases, there is a relatively wide range of regulations on the part of public authorities, despite the fact that from the point of view of the assumptions regarding the degree of regulation of their functioning by public authorities they should differ significantly. In practice, however, the model of deregulated public transport departed from its assumptions in pursuit of ensuring a high standard of transport services.

The public transport organizer plays a key role both in the one and the other system, which implements the strategies adopted by public authorities. These strategies are subordinated to obtaining a high standard of services and minimizing the negative impact of the entire mobility system in a given area on the natural environment. Both systems strive to integrate public transport throughout the metropolitan area. Integration concerns in particular transfer conditions, timetables, information and fares. There are also a number of innovations to increase the attractiveness of the services provided.

Both systems have operators employed by the organizer, although in a deregulated system this solution has a complementary importance. However, the scope of the organizer's interference in the transport offer is similar. Courses are maintained for social reasons and for the same reasons a certain range of entitlements to concession and free travel is applied. However, the examples presented show 
a different approach to free travel. In the regulated system, the most important are the social dimension, while in the deregulated transport, subordinated to obtaining a favorable urban travel structure from the point of view of achieving the goals of sustainable mobility policy. However, it can be assumed that this is not due to the specifics of both systems.

Both in the regulated and deregulated systems, operators are contracted to provide specific transport services. However, the scope and ground of contracting are different. But it is possible that the two systems are much more similar in terms of contracting.

\section{References}

Dydkowski, G. (2009), Czynniki powoływania zarządów transportu miejskiego, Komunikacja Publiczna, 3(36), p. 22.

Encyclopedia Britannica, www.britannica.com [Accessed 1 March 2019].

Florio, C.V., Florio, M., Perucca, G. (2013), User satisfaction and the organization of local public transport: Evidence from European cities, Transport Policy, 29, p. 210, doi: 10.1016/j. tranpol.2013.06.004.

Grzelec, K. (2011), Zarząd transportu miejskiego - zarządzanie czy administrowanie, Przegląd Komunikacyjny, 5-6, p. 31.

Leeds Supertram, www.railway-technolgy.com [Accessed 4 March 2019].

Plan zagospodarowania przestrzennego województwa pomorskiego (2009), UMWP, Gdańsk, p. 144.

Population Estimates for UK, England and Wales, Scotland and Northern Ireland - Office for National Statistics, www.ons.gov.uk [Accessed 1 March 2019].

Rucińska, D. (Ed.) (2015), Rynek ustug transportowych w Polsce. Teoria i praktyka, Polskie Wydawnictwo Ekonomiczne, Warszawa, p. 77.

transport-strategy-2040.pdf, www.westyorks-ca.gov.uk [Accessed 4 March 2019].

Ustawa z dnia 16 grudnia 2010 r. o publicznym transporcie zbiorowym, Journal of Laws of 2011, No. 5, item 13.

Ustawa z dnia 8 marca 1990 r. o samorządzie gminnym, Journal of Laws of 1990, No. 16, item 95.

Van de Welde, D.M. (1999), Organisational forms of enterpreneurship in public transport. Part 1: classifyinng, organisational forms, Transport Policy, pp. 147-157, doi: 10.1016/ S0967-070X(99)00016-5.

West Yorkshire Bus Strategy 2040, www.westyorks-ca.gov.uk [Accessed 4 March 2019].

White, P. (2017), Public Transport. Its planning, management and operation. Sixth Edition, Rout-

ledge, Londyn and New York, p. 3, 4, doi: 10.4324/9780203892282

www.arrivabus.co.uk [Accessed 5 March 2019].

www.firstgroup.com/leeds [Accessed 5 March 2019].

www.mzkwejherowo.pl [Accessed 7 March 2019].

www.wymetro.com [Accessed 5 March 2019].

www.ztm.gda.pl [Accessed 7 March 2019].

Wyszomirski, O. (2001a), Funkcjonowanie zderegulowanego lokalnego transportu pasażerskiego w Wielkiej Brytanii na przykładzie Leeds i Shefield, Część I, Transport Miejski, 5, p. 3.

Wyszomirski, O. (2001b), Funkcjonowanie zderegulowanego lokalnego transportu pasażerskiego w Wielkiej Brytanii na przykładzie Leeds i Shefield, Część II, Transport Miejski, 6, p. 13.

Wyszomirski, O. (Eds.) (2002), Gospodarowanie w komunikacji miejskiej, Wydawnictwo Uniwersytetu Gdańskiego, Gdańsk, p. 154. 
Zatti, A. (2011), New organizational models in European Local Public Transport: from Myth to Realistic, Ciriec 6, pp. 10-11, doi: 10.1111/j.1467-8292.2012.00476.x.

Zhang, C., Juan, Z., Lu, Z., Xiao, G. (2016), Do the organizational forms affect passenger satisfaction? Evidence from Chinese public transport service, Transportation Research Part A, 94, p. 131, doi: 10.1016/j.tra.2016.09.007.

\section{Corresponding author}

Olgierd Wyszomirski can be contacted at: o.wyszomirski@wp.pl 